\title{
Identification and molecular characterization of Zantedeschia mild mosaic virus, a new calla lily-infecting potyvirus
}

\author{
Brief Report \\ C.-H. Huang and Y.-C. Chang \\ Department of Plant Pathology and Microbiology, \\ National Taiwan University, Taipei, Taiwan \\ Received October 21, 2004; accepted December 13, 2004 \\ Published online February 10, 2005 (c) Springer-Verlag 2005
}

Summary. Tissue-cultured seedlings of calla lily (Zantedeschia spp.) with mild mosaic symptom were observed in Taiwan. A new potyvirus, Zantedeschia mild mosaic virus (ZaMMV), was identified in the diseased plants based on the result of ELISA, virion morphology and sequence data. In the host range test, ZaMMV only infected Philodendron selloum and Zantedeschia spp. causing systemic mosaic and mild mosaic symptom, respectively. The $3^{\prime}$-terminal region of the virus was amplified by RT-PCR from total RNA using a potyvirus-specific degenerate primer and an oligo-dT primer. Sequence analysis revealed that the highest amino acid sequence identity of the capsid protein (CP) gene between ZaMMV and thirty potyviruses was $55 \%$, and the highest nucleotide identity of $3^{\prime}$ untranslated region ( $3^{\prime} \mathrm{UTR}$ ) was $52 \%$. Therefore, in terms of species demarcating criteria, ZaMMV is a new species of the genus Potyvirus. From the result of phylogenetic analysis, ZaMMV should be a member of the Bean common mosaic virus subgroup. According to the deduced amino acid sequence of ZaMMV, the $\mathrm{N}$ terminus of the $\mathrm{CP}$ contained 39 glutamine residues before DAG motif. This unique sequence has never been discovered in plant viruses.

\section{*}

Zantedeschia spp., which originated from Africa and are commonly called calla lily, pig lily and arum lily, belong to the Araceae family and are classified into seven species and two subspecies [10]. In Taiwan, many cultivars of calla lily have been imported from New Zealand, the Netherlands and USA for producing cut flowers, breeding and also for establishing a micropropagation system. Viral diseases are one of the limiting factors for calla lily production in Taiwan as 
well as in other countries. Many viruses have been reported to infect calla lily including isolates of Dasheen mosaic virus (DsMV) [4, 17], Cucumber mosaic virus (CMV) [13], Konjak mosaic virus (KoMV), Bean yellow mosaic virus (BYMV), Tomato spotted wilt virus (TSWV), Impatiens necrotic spot virus (INSV), Alfalfa mosaic virus (AMV), Arabis mosaic virus (ArMV), Potato virus X(PVX), Tobacco rattle virus (TRV) [16], Turnip mosaic virus (TuMV) [3] and Zantedeschia mosaic virus (ZaMV) [2, 9]. Among them, DsMV, a member of the genus Potyvirus, is the most important virus of aroid plants and has been studied for a long time [22]. Although ZaMV was discovered only recently, it has become more prevalent in calla lilies than DsMV in Taiwan and Korea [9].

In 2001, tissue-cultured seedlings of Zantedeschia sp. cv. 'Black Magic' purchased from the Taiwan Seed Improvement and Propagation Station (TSIPS) were grown in a greenhouse. After one growing season, tubers were harvested, stored and replanted in the same condition. A new mild mosaic symptom was observed in some seedlings of calla lily (Fig. 1). A virus isolate, ZUN, was successfully transferred to Philodendron selloum by mechanical inoculation and then maintained on this systemic host plant. To determine the host range of ZUN isolate, inoculum was prepared by grinding the infected $P$. selloum tissues in 10 volumes of $0.01 \mathrm{M}$ sodium phosphate buffer $(\mathrm{pH} 7.2)$ and then rubbed onto 36 plant species representing 13 families (Table 1) which were predusted with 600-mesh Carborundum. At least five plants of each species were tested. Inoculated plants were kept at $25^{\circ} \mathrm{C}$, and monitored for symptom expression for one month and also for the contamination with CMV, DsMV, TuMV or ZaMV by indirect ELISA (I-ELISA) according to the protocol of Agdia Inc. (Agdia Inc., IN, USA). Crude sap of ZUN-infected leaf tissue was placed onto the carbon

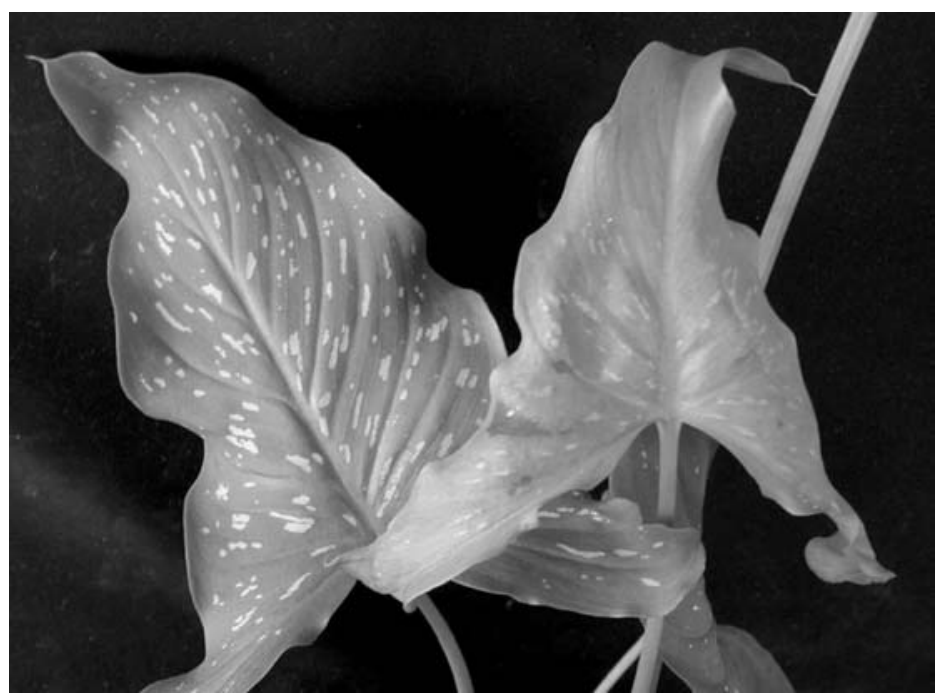

Fig. 1. Mild mosaic symptoms on the leaf of ZaMMV-infected calla lily (right). Healthy plant is shown on the left 
Table 1. Symptoms of Zantedeschia mild mosaic virus (ZaMMV) on test plants

\begin{tabular}{|c|c|c|}
\hline Family & Species & Symptoms $^{\mathrm{a}}$ \\
\hline Aizoaceae & Tetragonia tetragonioides & - \\
\hline \multirow[t]{4}{*}{ Amaranthaceae } & Amaranthus mangostanus & - \\
\hline & A. viridis & - \\
\hline & Celosia argentea & - \\
\hline & Gomphrena globosa & - \\
\hline Apocynaceae & Catharanthus roseus & - \\
\hline \multirow[t]{2}{*}{ Araceae } & Philodendron selloum & SM, VC, LD \\
\hline & Zantedeschia spp. & SMM, VC \\
\hline \multirow[t]{4}{*}{ Brassicaceae } & Arabidopsis thaliana & - \\
\hline & Brassica chinensis & - \\
\hline & B. juncea & - \\
\hline & Raphanus sativas & - \\
\hline Caricaceae & Carica papaya & - \\
\hline \multirow[t]{2}{*}{ Chenopodiaceae } & Chenopodium amaranticolor & - \\
\hline & C. quinoa & - \\
\hline Compositae & Crassocephalum crepidioide & - \\
\hline Convolvulaceae & Ipomoea aquatica & - \\
\hline \multirow[t]{2}{*}{ Cucurbitaceae } & Cucurbita pepo & - \\
\hline & Cucumis sativus & - \\
\hline \multirow[t]{7}{*}{ Fabaceae } & Cassia occidentalis & - \\
\hline & Phaseolus calcaratu & - \\
\hline & P. limensis & - \\
\hline & P. radiatus & - \\
\hline & P. vulgari & - \\
\hline & Pisum sativum & - \\
\hline & Vigna unguiculata & - \\
\hline \multirow[t]{9}{*}{ Solanaceae } & Datura stramonium & - \\
\hline & Lycopersicon escultentum & - \\
\hline & Nicotiana benthamiana & - \\
\hline & N. clevelandii & - \\
\hline & N. occidentalis & - \\
\hline & N. tabacum var. Samsun & - \\
\hline & N. tabacum var. White burley & - \\
\hline & Petunia hybrida & - \\
\hline & Solanum tuberosum & - \\
\hline Umbelliferae & Coriandrum sativum & - \\
\hline
\end{tabular}

\footnotetext{
${ }^{a}$ Abbreviation of symptoms: leaf distortion (LD), systemic mosaic (SM), systemic mild mosaic (SMM), veinal chlorosis (VC) and no infection (-)

film-coated copper grid, and stained with $2 \%$ phosphotungstic acid (PTA). The virus particles were observed and photographed by an electron microscope. Plant total RNAs were extracted from $100 \mathrm{mg}$ of tissue following the protocol of Plant Total RNA Extraction Miniprep System (Viogene, Sunnyvale, CA, USA). The first-strand cDNA was then synthesized using AMV reverse transcriptase (Promega, Madison, WI, USA) and dT-Bam primer (5'-AGCTGGATCC $(\mathrm{T})_{18^{-}} 3^{\prime}$ ).
} 
PCR reactions were carried out using dT-Bam and PNIbF1 (5'-GGBAAYA ATAGTGGNCAACC-3') primers [8] and DyNAzyme ${ }^{\mathrm{TM}}$ II DNA polymerase (Finnzymes Inc., Espoo, Finland) according to the manufacturer's protocol. RTPCR products were analyzed in a $1 \%$ agarose gel and desired cDNA fragments were purified from the agarose gel by GFX ${ }^{\mathrm{TM}}$ PCR DNA and Gel Band Purification Kit (Amersham Pharmacia Biotech, Piscataway, NJ, USA). The purified fragments were ligated with pGEM-T ${ }^{\circledR}$ Easy Vector (Promega, Madison, WI, USA) and transformed into E. coli DH5 $\alpha$. Two independent clones were selected for sequencing. DNA sequencing was performed by ABI PRISM ${ }^{\circledR} 310$ Genetic Analyzer using ABI PRISM ${ }^{\circledR}$ BigDye $^{\text {TM }}$ terminator cycle sequencing ready reaction kit (Applied Biosystems, Foster City, CA, USA). Nucleotide sequences were assembled and amino acid sequences were predicted using Wisconsin GCG Package version 10.3 (Accelrys Inc., San Diego, CA, USA). Multiple sequences were aligned by PILEUP program in Wisconsin GCG Package and verified by ClustalX [19]. Phylogenetic analysis was performed with neighbor-joining (NJ) method using programs in PHYLIP version 3.573c [6]. Genetic distances between pairs of amino acid sequences were calculated using PROTDIST (Kimura formula). Phylogenetic trees were constructed by a distance matrix method (NEIGHBOR) using the original data set and 1000 bootstrap data sets generated by the program SEQBOOT from the original set. The bootstrap values and the consensus tree were generated by the program CONSENSE. The program TREEVIEW was used to draw the phylogenetic tree [14].

Among 36 plant species belonging to 13 families tested, ZUN successfully infected two aroid plants, calla lily (Zantedeschia spp.) and P. selloum (Table 1). Inoculated calla lilies produced veinal chlorosis and later became systemic mild mosaic symptoms similar to the symptoms observed before. Whereas, P. selloum appeared systemic mosaic symptoms, veinal chlorosis and sometimes leaf distortion (Table 1). In order to know if these symptomatic plants in host range test were contaminated with calla-infecting viruses commonly found in Taiwan, I-ELISA assays were performed. None of the samples reacted positively for the presence of CMV, DsMV, TuMV or ZaMV; however, the anti-poty group monoclonal antibody (Agdia Inc., Elkhart, IN, USA) gave a positive result (data not shown). In addition, the remaining 34 plant species did not produce symptom nor react to anti-poty group monoclonal antibody one month after inoculation. When crude sap of the ZUN-infected leaves was stained with 2\% PTA, flexuous filaments about $680 \mathrm{~nm}$ in length were observed by TEM (Fig. 2). From the results of I-ELISA and virion morphology, ZUN was a potyvirus, and did not react with antibodies to DsMV, TuMV or ZaMV, the potyviruses found in Taiwan.

To identify the unknown potyvirus, ZUN, a potyvirus-specific primer pair was used to RT-PCR amplify the $3^{\prime}$ terminal region of the genome. Total RNA of the diseased plant was extracted, a $1.8-\mathrm{kb}$ fragment was amplified, and cloned into pGEM-T ${ }^{\circledR}$ Easy vector. Two independent clones, pZUN7 and pZUN8, were sequenced and analyzed. The sequences of both clones had $1845 \mathrm{nt}$ excluding poly(A) tail which included 633 nt of the NIb gene, the complete $\mathrm{CP}$ gene of $972 \mathrm{nt}$ and $3^{\prime} \mathrm{UTR}$ of $240 \mathrm{nt}$. This nucleotide sequence was first checked against 


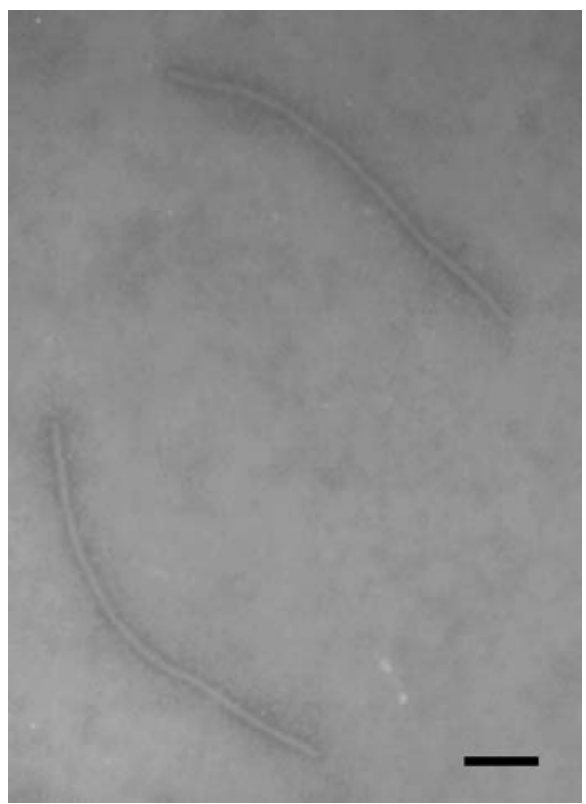

Fig. 2. Electron micrograph of ZaMMV particles. Crude sap of ZaMMV-infected Zantedeschia spp. was stained with $2 \%$ PTA. The bar represents $100 \mathrm{~nm}$

the international sequence databases using the BLAST program (National Center for Biotechnology Information). Subsequently, 30 potyviruses revealing high homology with ZUN were selected for sequence comparison. The results of multiple sequence alignment indicated that the percentage identities of the $\mathrm{CP}$ amino acid sequences and 3'UTR nucleotide sequences between ZUN and other potyviruses were $42-55 \%$ and $9-52 \%$, respectively (Table 2). BCMV-R had both the highest identical amino acids of the CP and nucleotide sequences of $3^{\prime} \mathrm{UTR}$ among potyviruses compared with ZUN (Table 2). Hence, according to the species demarcating criteria in the $7^{\text {th }}$ ICTV report [20], ZUN is proved to be a new species of the genus Potyvirus. It was designated as Zantedeschia mild mosaic virus (ZaMMV) according to the mild mosaic symptom it induced on calla lily. The nucleotide sequence of ZaMMV was deposited in GenBank with the accession number AY626825. Phylogenetic analysis of the complete amino acid sequence of the CP revealed that ZaMMV is clustered with BCMV, BCMNV, DsMV, SMV and ZYMV (Fig. 3). Accordingly, it should be a new member of BCMV subgroup that was first proposed by Berger et al. [1].

The conserved NIa-Pro cleavage site, VXXQ/A, was identified between the $\mathrm{NIb}$ and CP coding regions of ZaMMV as for DsMV (Fig. 4). The DAG motif relating to aphid-transmission [12] is located at amino acid residues of 51 to 53 of the CP gene. Surprisingly, the N terminus of the CP of ZaMMV contained 39 glutamine residues before the DAG motif (Fig. 4). To confirm the existence of the polyglutamine sequence in the $\mathrm{CP}$ of $\mathrm{ZaMMV}$, we did cDNA cloning from another two plants, and all sequenced clones contained this unusual sequence (data not shown). To our knowledge, this is the first time that this kind of polyglutamine sequence was discovered in plant viruses. 
Table 2. Percentage of sequence identities between the CP and $3^{\prime} \mathrm{UTR}$ of ZaMMV and those of 30 distinct potyviruses

\begin{tabular}{|c|c|c|c|c|}
\hline Virus $^{\mathrm{a}}$ & $\mathrm{CPaa}^{\mathrm{b}}$ & $\mathrm{CPnt}^{\mathrm{b}}$ & $3^{\prime} \mathrm{UTR}^{\mathrm{c}}$ & Accession number \\
\hline BCMNV-NL3 & 53 & 53 & 42 & U19287 \\
\hline BCMV-R & 55 & 56 & 52 & AJ312437 \\
\hline BYMV-MB4 & 44 & 48 & 16 & D83749 \\
\hline ClYVV-30 & 43 & 46 & 17 & AB011819 \\
\hline DsMV-M13 & 52 & 58 & 29 & AJ 298033 \\
\hline JGMV & 48 & 52 & 9 & $\mathrm{Z} 26920$ \\
\hline JYMV-1 & 47 & 49 & 19 & $\mathrm{AB} 016500$ \\
\hline $\mathrm{LMoV}-\mathrm{Sb}$ & 45 & 47 & 20 & AJ564636 \\
\hline LMV-O & 48 & 50 & 23 & X97704 \\
\hline LYSV-Y & 46 & 49 & 10 & AJ307057 \\
\hline MDMV-B & 46 & 48 & 21 & AJ001691 \\
\hline OYDV-Y & 44 & 46 & 22 & AJ510223 \\
\hline PeMoV-M & 46 & 49 & 20 & AF023848 \\
\hline PepMoV-CA & 46 & 48 & 27 & M96425 \\
\hline PPV-M & 44 & 52 & 18 & AJ243957 \\
\hline PRSV-HA & 44 & 53 & 16 & S46722 \\
\hline PSbMV-DPD1 & 44 & 50 & 20 & D10930 \\
\hline PVA & 45 & 47 & 18 & $\mathrm{Z} 21670$ \\
\hline PVV-DV42 & 43 & 48 & 11 & AJ 243766 \\
\hline PVY-N & 49 & 47 & 22 & $\mathrm{X} 12456$ \\
\hline SCMV-A & 46 & 53 & 22 & AJ 278405 \\
\hline SMV-G2 & 53 & 53 & 46 & $\mathrm{~S} 42280$ \\
\hline SPFMV-S & 43 & 53 & 20 & D86371 \\
\hline SrMV-H & 48 & 53 & 23 & U57358 \\
\hline TEV & 45 & 47 & 17 & M15239 \\
\hline TuMV & 44 & 48 & 18 & D10927 \\
\hline TVMV & 42 & 46 & 25 & X04083 \\
\hline YMV-IC & 46 & 49 & 18 & U42596 \\
\hline ZaMV-ZAN & 44 & 48 & 15 & AF332872 \\
\hline ZYMV-RI & 52 & 53 & 31 & L29569 \\
\hline
\end{tabular}

${ }^{a}$ Full names of the viruses are NL3 strain of Bean common mosaic necrosis virus (BCMNV-NL3), R isolate of Bean common mosaic virus (BCMV-R), MB4 strain of Bean yellow mosaic virus (BYMV-MB4), No. 30 strain of Clover yellow vein virus (ClYVV-30), M13 isolate of Dasheen mosaic virus (DsMV-M13), Johnsongrass mosaic virus (JGMV), No. 1 strain of Japanese yam mosaic virus (JYMV-1), Sb isolate of Lily mottle virus (LMoV-Sb), O strain of Lettuce mosaic virus (LMV-O), Yuhang GYH isolate of Leek yellow stripe virus (LYSV-Y), Bulgaria strain of Maize dwarf mosaic virus (MDMV-B), Yuhang isolate of Onion yellow dwarf virus (OYDV-Y), M strain of Peanut mottle virus (PeMoV-M), California strain of Pepper mottle virus (PepMoV-CA), M strain of Plum pox virus (PPV-M), Hawaii isolate of Papaya ringspot virus (PRSV-HA), DPD1 strain of Pea seed-borne mosaic virus (PSbMV), Potato virus A (PVA), DV42 isolate of Potato virus V (PVV-DV42), N strain of Potato virus $Y$ (PVY-N), A strain of Sugarcane mosaic virus (SCMV-A), G2 strain of Soybean mosaic virus (SMV-G2), S strain of Sweet potato feathery mottle virus (SPFMV-S), $\mathrm{H}$ strain of Sorghum mosaic virus (SrMV-H), Tobacco etch virus (TEV), Turnip mosaic virus (TuMV), Tobacco vein mottling virus (TVMV), Ivory Coast strain of Yam mosaic virus (YMV-IC), ZAN strain of Zantedeschia mosaic virus (ZaMV-ZAN), and Reunion Island of Zucchini yellow mosaic virus (ZYMV-RI)

${ }^{\mathrm{b}}$ Figure represents percentage of amino acid and nucleotide sequence identity

${ }^{c}$ Figure represents percentage of nucleotide sequence identity 


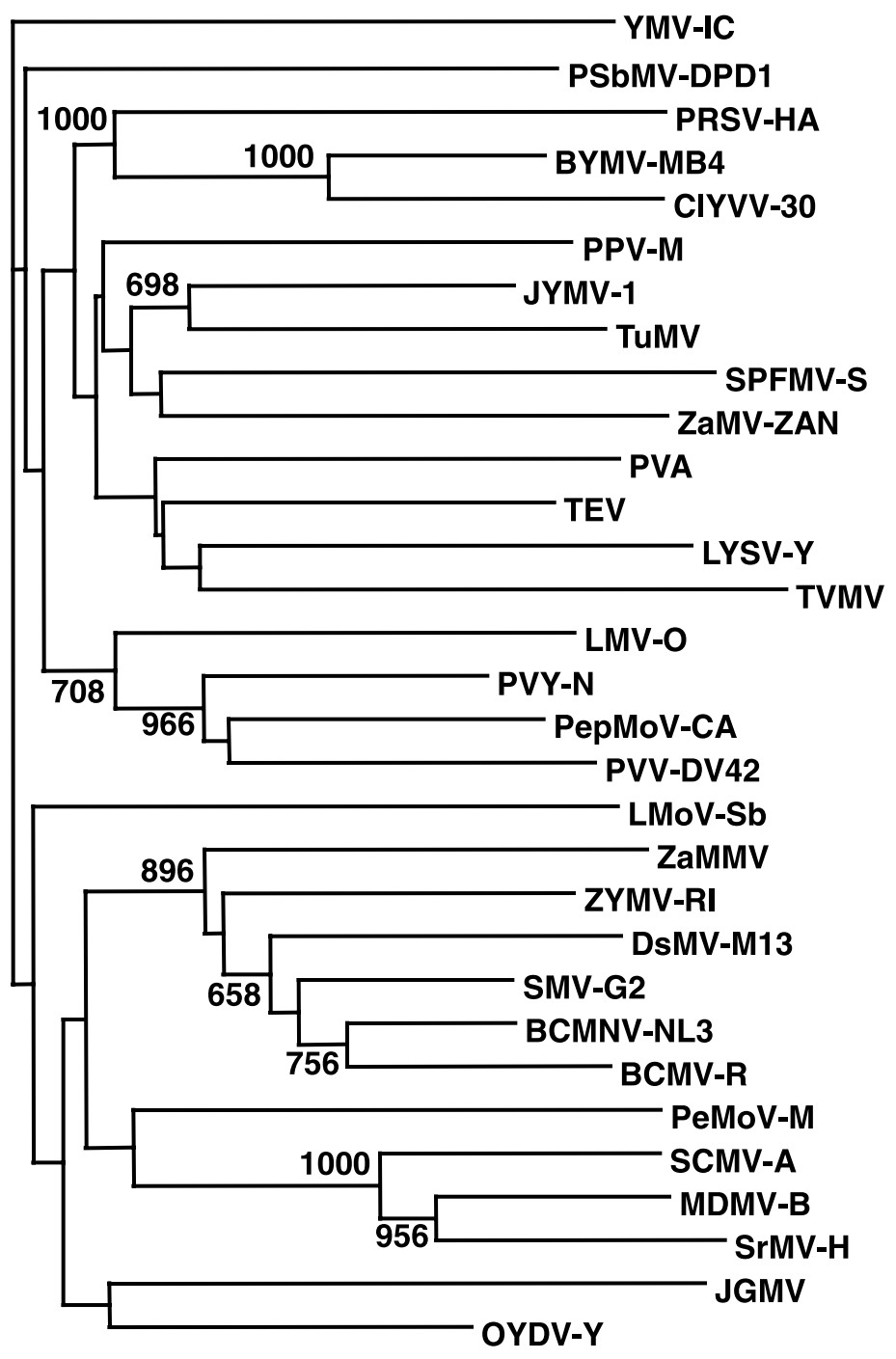

0.1

Fig. 3. Phylogenetic relationship of ZaMMV and members of the genus Potyvirus based on the $\mathrm{CP}$ at the amino acid level. Multiple sequence alignment was generated using the PILEUP program and verified by Clustal X. The tree was constructed by the neighbor-joining algorithm based on calculations from pairwise amino acid sequence distances. The horizontal branch lengths are proportional to the genetic distance. The number shown at branch point indicates bootstrap value that was subjected to 1000 bootstrap replicates. Only those values above 650 are shown

According to I-ELISA test results, virus particle morphology, and the sequence of the $3^{\prime}$ terminal region, a virus identified in the uninoculated tissue-cultured calla lilies was shown to be a new potyvirus referred to as Zantedeschia mild mosaic virus (ZaMMV). In addition to DsMV, TuMV [3] and ZaMV [2], ZaMMV is another potyvirus found to infect calla lilies in Taiwan. The 1845-nt sequence of ZaMMV was determined, starting from the $3^{\prime}$ terminus of the NIb gene to $3^{\prime}$ UTR. 


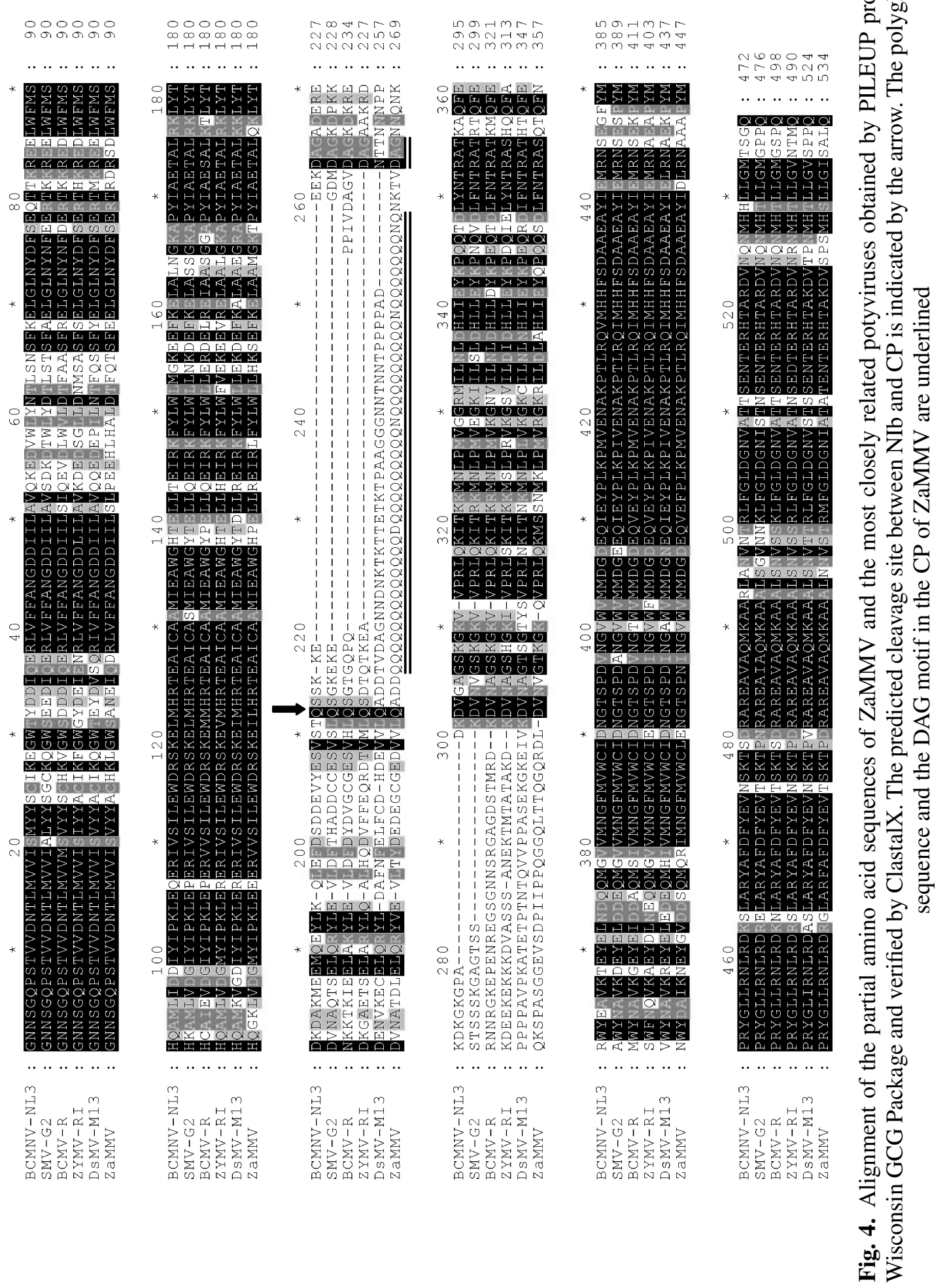


According to the result of multiple sequence alignment of the $\mathrm{CP}$ amino acid sequence, BCMV-R, BCMNV-NL3, SMV-G2, DsMV-M13 and ZYMV-RI had 52-55\% identities when compared with ZaMMV (Table 2). Because all these potyviruses are classified as members of the BCMV subgroup in the family Potyviridae [1], it is reasonable to conclude that ZaMMV belongs to the same subgroup. This speculated relationship was confirmed by phylogenetic analysis (Fig. 3).

Some potyviruses have special amino acid sequences at the $\mathrm{N}$ terminus of the $\mathrm{CP}$ after the DAG motif. For example, there are repetitive sequences, $(\text { GNNTNTNTNT) })_{3}$ and six proline residues, after the DAG motif of the CP of DsMV-LA isolate [15]. Similar features, such as $(\mathrm{KEKEKQ})_{2}(\mathrm{KE})_{2}$ occurs in the CP of PRSV-HA [21], and KEKEKE in the CP of ZaMV-ZAN (unpublished data), were also found downstream the DAG motif. In contrast, an unusual, repetitive glutamine sequence at the $\mathrm{N}$ terminal region of ZaMMV CP is upstream the DAG motif. This is the first example of such unique feature found in potyviruses or other plant viruses. The mechanism of producing such a polyglutamine repeat is still unknown, but this may be similar to the repetitive sequence of other potyviruses that is thought to be caused by polymerase slippage [7].

The dominant epitopes of potyvirus virions are the variable terminal parts of the capsid protein, especially the $\mathrm{N}$-terminal part. Some reports revealed that about 30 amino acids of the $\mathrm{N}$ terminus of $\mathrm{CP}$ were exposed on the surface of virus particle [18] and were related to potyvirus movement $[5,11]$. The repetitive sequence of ZaMMV CP was composed of 39 glutamine residues which were likely exposed on the surface of virion, if not degraded or processed. Future studies might focus on the function(s) of this polyglutamine tract.

\section{Acknowledgements}

We thank Dr. Yung-An Lee for critically reviewing the manuscript. This study was partially supported by the Council of Agriculture, Executive Yuan, Taiwan, R.O.C.

\section{References}

1. Berger PH, Wyatt SD, Shiel PJ, Silbernagel MJ, Druffel K, Mink GI (1997) Phylogenetic analysis of the Potyviridae with emphasis on legume-infecting potyviruses. Arch Virol 142: 1979-1999

2. Chang YC, Chen YL, Chung FC (2001) Mosaic disease of calla lily caused by a new potyvirus in Taiwan. Plant Dis 85: 1289

3. Chen CC, Chao CH, Chen CC, Yeh SD, Tsai HT, Chang CA (2003) Identification of Turnip mosaic virus isolates causing yellow stripe and spot on calla lily. Plant Dis 87: 901-905

4. Chen J, Chen JP, Chen JS, Adams MJ (2001) Molecular characterization of an isolate of Dasheen mosaic virus from Zatedeschia aethiopica in China and comparisons in the genus Potyvirus. Arch Virol 146: 1821-1829

5. Dolja VV, Haldeman-Cahill R, Montgomery AE, Vandenbosch KA, Carrington JC (1995) Capsid protein determinants involved in cell-to-cell and long distance movement of tobacco etch potyvirus. Virology 206: 1007-1016 
6. Felsenstein J (1993) PHYLIP (Phylogeny Inference Package) version 3.5c. Distributed by the author. Department of Genetics, University of Washington, Seattle

7. Hancock JM, Chaleeprom W, Chaleeprom W, Dale J, Gibbs A (1995) Replication slippage in the evolution of potyviruses. J Gen Virol 76: 3229-3232

8. Hu WC, Chang YC (2004) A new mosaic disease of Amazon lily in Taiwan. Plant Pathol 53: 240

9. Kwon SB, Ha JH, Yoon JY, Ryu KH (2002) Zantedeschia mosaic virus causing leaf mosaic symptom in calla lily is a new potyvirus. Arch Virol 147: 2281-2289

10. Kuehny JS (2000) Crop reports: Calla history and culture. HortTechnology 10: 267-274

11. Lopez-Moya JJ, Pirone TP (1998) Charge changes near the $\mathrm{N}$ terminus of the coat protein of two potyviruses affect virus movement. J Gen Virol 79: 161-165

12. Lopez-Moya JJ, Wang RY, Pirone TP (1999) Context of the coat protein DAG motif affects potyvirus transmissibility by aphids. J Gen Virol 80: 3281-3288

13. Mokra V, Gotzova B (1994) Identification of virus infections in Dieffenbachia and Zantedeschia in Czechoslovakia. Acta Hort 377: 361-362

14. Page RDM (1996) TREEVIEW: an application to display phylogenetic trees on personal computers. Comput Appl Biosci 12: 357-358

15. Pappu SS, Pappu HR, Rybicki EP, Niblett CL (1994) Unusual amino-terminal sequence repeat characterizes the capsid protein of dasheen mosaic potyvirus. J Gen Virol 75: 239-242

16. Pham K, Langeveld SA, Lemmers MEC, Derks AFLM (2002) Detection and identification of potyviruses in Zantedeschia. Acta Hort 568: 143-148

17. Rana GL, Vovlas C, Zettler FW (1983) Manual transmission of dasheen mosaic virus from Richardia to nonaraceous hosts. Plant Dis 67: 1121-1122

18. Shukla DD, Ward CW (1989) Structure of potyvirus coat proteins and its application in the taxonomy of the potyvirus group. Adv Virus Res 36: 273-314

19. Thompson JD, Gibson TJ, Plewniak F, Jeanmougin F, Higgins DG (1997) The ClustalX windows interface: flexible strategies for multiple sequence alignment aided by quality analysis tools. Nucleic Acids Res 25: 4876-4882

20. Van Regenmortel MHV, Fauquet CM, Bishop DHL, Carstens EB, Estes MK, Lemon SM, Maniloff J, Mayo MA, McGeoch DJ, Pringle CR, Wickner RB (2000) Virus Taxonomy. Seventh Report of the International Committee on Taxonomy of Viruses. Academic Press, London

21. Yeh SD, Jan FJ, Chiang CH, Doong TJ, Chen MC, Chung PH, Bau HJ (1992) Complete nucleotide sequence and genetic organization of papaya ringspot virus RNA. J Gen Virol 73: 2531-2541

22. Zettler FW, Foxe MJ, Hartman RD, Edwardson JR, Christie RG (1970) Filamentous viruses infecting dasheen and other araceous plants. Phytopathology 60: 983-987

Author's address: Dr. Ya-Chun Chang, Department of Plant Pathology and Microbiology, National Taiwan University, No. 1, Sec. 4, Roosevelt Road, Taipei 10617, Taiwan; e-mail: ycchang@ntu.edu.tw 